but assumed I wrote my column from Broadmoor, having been indefinitely detained for Grievous Bodily Humour and Murder of the English Language. Wilder suggestions have been made, including one that I am not a doctor at all, but some hack from Grub Street (possibly Bernard Levin or Auberon Waugh) and the President has secretly created me an Honorary Fellow 'in pectore'. The Collegiate Trainees have even doubted that I am human, and have suggested that I might be a great grandson of Archie, that poetical cockroach who wrote of Mehitabel for Don Marquis by leaping alternately on separate keys of the typewriter.

\section{Conclusions}

Today all will be made known and the last veil removed revealing the great secret which is that there is no secret. My life history is humdrum, since I do not exist. I am a crowd [We are a crowd, surely-Ed.]. At one stage I consisted of a bevy of Psychiatric Wits detained in a compound at the back of the College. This drastic attempt by the Editor to improve the quality of the Bulletin failed, since many of us absconded, and having stayed away for 28 days were released. Today, alas, I am only a ghost. At times the minds of College members become overheated as they contemplate the follies and absurdities of modern psychiatric practice. The steam that rises from these minds forms a miasma of pale ectoplasm, which can be found drifting (like the mist that does be coming over the bog on the Celtic fringes of these islands) and may be confused with the dust from the rebuilding operations at the College. From the frail ghostly presence flows the steady stream of lucid abuse which irregularly sullies the pages of the Bulletin. I have in the past, and will again in the future, sign myself 'Ezra the Scribe', but today we will sign ourselves.

EzRA (the Collective Scribes)

\section{Editorial Note}

It is quite correct that there are many shades of Ezra. Today's contribution was compiled (like many College documents) by various separate sections and committees. If at times there are inconsistencies and the joins show, it is no worse in this respect than some other College documents. Further contributions from all parts of the globe will be welcome for the column of Ezra the Scribe.

\title{
Tea and Sympathy (a Psychiatrist's Lament).
}

\author{
'It must be marvellous \\ To be married \\ To a psychiatrist, \\ I bet, \\ He listens to all \\ Your problems.' \\ People like to talk \\ About themselves. \\ It feeds the soul \\ With tasty morsels \\ Of satisfaction. \\ I can't listen \\ To all this, \\ Just soaking up \\ Emotional garbage \\ Ad infinitum. \\ I must breathe.
}

\author{
So don't tell me \\ About mum \\ Or dad and \\ Aunt Ada. \\ I'll only \\ Look bored. \\ You seem to think \\ I should \\ Be able to \\ Produce a remedy \\ For your ills \\ And moans.
}

But Tea and Sympathy

Is no good

If you basically

Can't stand

Being told

To shut up. 